\title{
Orchid diversity in a logging concession in Tabalong District, South Kalimantan, Indonesia
}

\author{
DWI MURTI PUSPITANINGTYAS ${ }^{\boldsymbol{v}}$ \\ Center for Plant Conservation and Botanic Gardens (Bogor Botanic Gardens), Indonesian Institute of Sciences. Jl. Ir. H. Juanda No. 13, Bogor 16122, \\ West Java, Indonesia. Tel. +62-251-8322187. Fax. +62-251-8322187, `email: puspitakrb@yahoo.com
}

Manuscript received: 3 July 2020. Revision accepted: 28 October 2020.

\begin{abstract}
Puspitaningtyas DM. 2020. Orchid diversity in a logging concession in Tabalong District, South Kalimantan, Indonesia. Biodiversitas 21: 5455-5464. Borneo is the third largest island in the world, and considered the "island of orchids" since it has approximately 2.500-3.000 species of orchids, equivalent to $10 \%$ of the orchids in the world. The aim of the research was to study orchid diversity in a logging concession in the village of Dambung Raya, Ara Bintang Sub-district, Tabalong District, South Kalimantan Province, Indonesia. This research also collected living specimens of orchid to be grown in Bogor Botanic Gardens, West Java, Indonesia, and Banua Botanic Gardens, Banjarbaru, South Kalimantan, Indonesia. The orchid inventory was carried out using explorative method. The study recorded 64 species of epiphyte orchids and one species of terrestrial orchid, altogether belong to 27 genera. Some interesting orchid species found in this area included Acriopsis spp., Aerides odorata Lour, Coelogyne spp. (C. motleyi Rolfe ex J.J.Wood, D.A.Clayton \& C.L.Chan, C. foerstermannii Rchb.f., C. rochussenii de Vriese, C. pandurata Lindl.), Grammatophyllum speciosum Blume,Liparis spp., Pteroceras teres (Blume) Holttum, Thrixspermum raciborskii J.J.Sm. subsp. brevipollinium P. O'Byrne \& A. Ent., and Thecostele alata (Roxb.) EC Parish \& Rchb.f. Orchid endemic to Borneo found in this area were Coelogyne motleyi Rolfe ex JJ Wood, DA Clayton \& CL Chan, Cleisostoma brachystachys (Ridl.) Garay and Thrixspermum raciborskii J.J.Sm. subsp. brevipollinium $\mathrm{P}$. O'Byrne \& A. Ent.
\end{abstract}

Keywords: Inventory, orchid, South Kalimantan, Tabalong

\section{INTRODUCTION}

Borneo is the third largest island in the world. The island is known as the center of biological diversity (Whitmore 1984). According to van Steenis (1971), Borneo has 25,000 species of flowering plants or $10 \%$ of all flora in the world. Ashton (1982) explains that there are approximately 3000 species of trees, including 267 species of Dipterocarpaceae grow on Borneo in which $58 \%$ of them are endemic species. Borneo also has a high level of orchid diversity with 2500-3000 species of orchid species described from the island, or equivalent to $10 \%$ of the total number of orchids in the world (Whitmore 1984; Lamb 1991). Of these $30-40 \%$ of the species are endemic orchids to Borneo. As such, Borneo is often considered as "orchid island" (Chan et al. 1994).

The floristic diversity in Borneo, including orchid, is the mix of floristic elements from Australia and Asia land, making it is very rich in diversity (Chan et al. 1994). Besides this biogeographical mixture of two continents, the high diversity of plant species in Borneo is closely related to several factors including topography, altitude, geology, soil type, climate, and ecosystem diversity (MacKinnon et al. 1996). Borneo has various types of forest ecosystems such as mangrove forests, peat forests, peat swamp forests, kerangas forests, lowland forests, limestone forests, mountain forests, and coastal forests.

The diversity of orchid species generally increases with altitude in Dipterocarps forest (Chan et al. 1994). Most species of orchids prefer to grow in mountainous forests between $500 \mathrm{~m}$ and $1500 \mathrm{~m}$ above sea level (Comber 1990). However, other habitats in Borneo such as the mangroves can be much poorer in orchid species. Very poor information of the orchid flora of the mangrove forests due to the difficulty of walking through them.

Many Asian orchids are threatened with extinction because of over-collection and habitat destruction (Park et al. 2000). The major causes of plant endangerment in Indonesia are biological factors, habitat loss, over-exploitation, and natural factors. For orchids, biological factors, habitat loss, and over-exploitation for economic purposes are the most important factors that threaten orchids in Indonesia (Budiharta et al. 2011). Orchid species are the most highly threatened species, compared to other threatened species of Indonesia. There are about 203 species (39\% of threatened species of Indonesia) (WCMC 1995).

Borneo's orchids are also at an alarming rate, due to loss of natural habitat caused by fires, forest destruction, and illegal logging. Increased exploitation of the forests, especially in West Borneo, including gold mining, forest fires, and illegal burning, has led to the extinction of hundreds of orchid species. Economic factors, including illegal collecting and selling of wild orchids by collectors (orchid lovers), along with increasing consumer demand for orchids, also contribute to the endangerment of Borneo's native orchids (Siregar 2008).

Only half of Borneo's forest cover remains today, down from $75 \%$ in the mid-1980s. With a current deforestation 
rate of 1.3 million hectares per year, only peat and montane forests would survive in the coming years (WWF 2020). In 2001, South Kalimantan had 722 kha of primary forest, extending over $19 \%$ of its land area. In 2019, it lost $4.12 \mathrm{kha}$ of primary forest (Global Forest Watch 2020).

Recently Indonesian orchids have been included as a part of the Malesian flora subject to be investigated. J.B. Comber from England has published Orchids of Java (1990) and Orchid of Sumatra (2001) which are very important contributions to the flora of the most highly populated island in Indonesia. Currently there are many authors from abroad who publish Indonesian orchid species richness. The first volume of Orchids of Borneo has been published as part of the estimated 20 volumes to be written by the Kew \& Leiden group, such as: Orchids of Borneo Vol. I (Chan et al., 1994), Orchids of Borneo Vol. II (Vermeulen, 1991), Orchids of Borneo Vol. III (Wood, 1997). Orchids of Borneo Vol. IV (Wood 2003), Dendrobium of Borneo (Wood 2013).

Botanical exploration and research are important efforts in plant conservation, both in situ and ex-situ. Moreover, the exploration could take place in threatened landscapes, such as logging concession and mining concession, so that information related to botanical diversity in such landscapes can be collected before it is lost. Despite collecting data, botanical exploration would be more beneficial if this activity could also collect living plant specimens to be collected in ex-situ conservation areas such as botanical gardens and arboretum. Furthermore, gathering information on native Bornean orchids was stimulated by the large variety of species found in Borneo, and also the lack of literature and specimen references available in South Kalimantan. The aim of the research was to study orchid diversity in a logging concession in Tabalong District, South Kalimantan Province, Indonesia. In logging areas, there is a high risk of declining orchid populations or even loss of orchid species in its natural habitat. This research also collected living specimens of orchid to be grown in Bogor Botanic Gardens, West Java,
Indonesia, and Banua Botanic Gardens, Banjarbaru, South Kalimantan, Indonesia. Ex-situ conservation of living orchids in Botanic Gardens is very urgent to be done to save orchid species from extinction in nature.

\section{MATERIALS AND METHODS}

\section{Study area and period}

The study was conducted in the area of a logging concession located in the village of Dambung Raya, Bintang Ara Sub-district, Tabalong District, South Kalimantan Province, Indonesia. The concession managed forest area of 87,241 hectares. The study site was located between S 01\%40'10.9"-E $115^{\circ} 29^{\prime} 09.1^{\prime \prime}$ and S 01\%42'41.7"-E $115^{\circ} 26^{\prime} 08.8^{\prime \prime}$. The exploration was conducted between 22 October-20 November 2013. The topography of the forest area is a hilly mountain with steep slopes from $0-40 \%$, altitude between $200-600 \mathrm{~m}$. The soil consists of sandstone, limestone, rock and limestone, clay yellowish-white, Red Yellow Podsolic, Red Yellow Podsolic Latosol complex, and Litosol. Its forests are dominated by species of Dipterocarpaceae family (Imanuddin and Wahjono 2007).

\section{Data collection}

The study was conducted using explorative methods (Hidayat et al. 2017; Partomihardjo and Rahajoe 2004). The living materials of orchid was identified into species level based on the morphological characteristics, in particular the flower. For specimen not in flowering stage, an initial identification was made to genus level then the living material was brought to Bogor Botanic Gardens and Banua Botanic Gardens for ex situ conservation. Plant samples were taken and collected only 1-5 specimens for species that are abundant in the field. Then to support in situ conservation, species that rarely found were not taken sample and were only recorded or photographed for documentation. Whenever the flower was appearing, further identification was conducted.
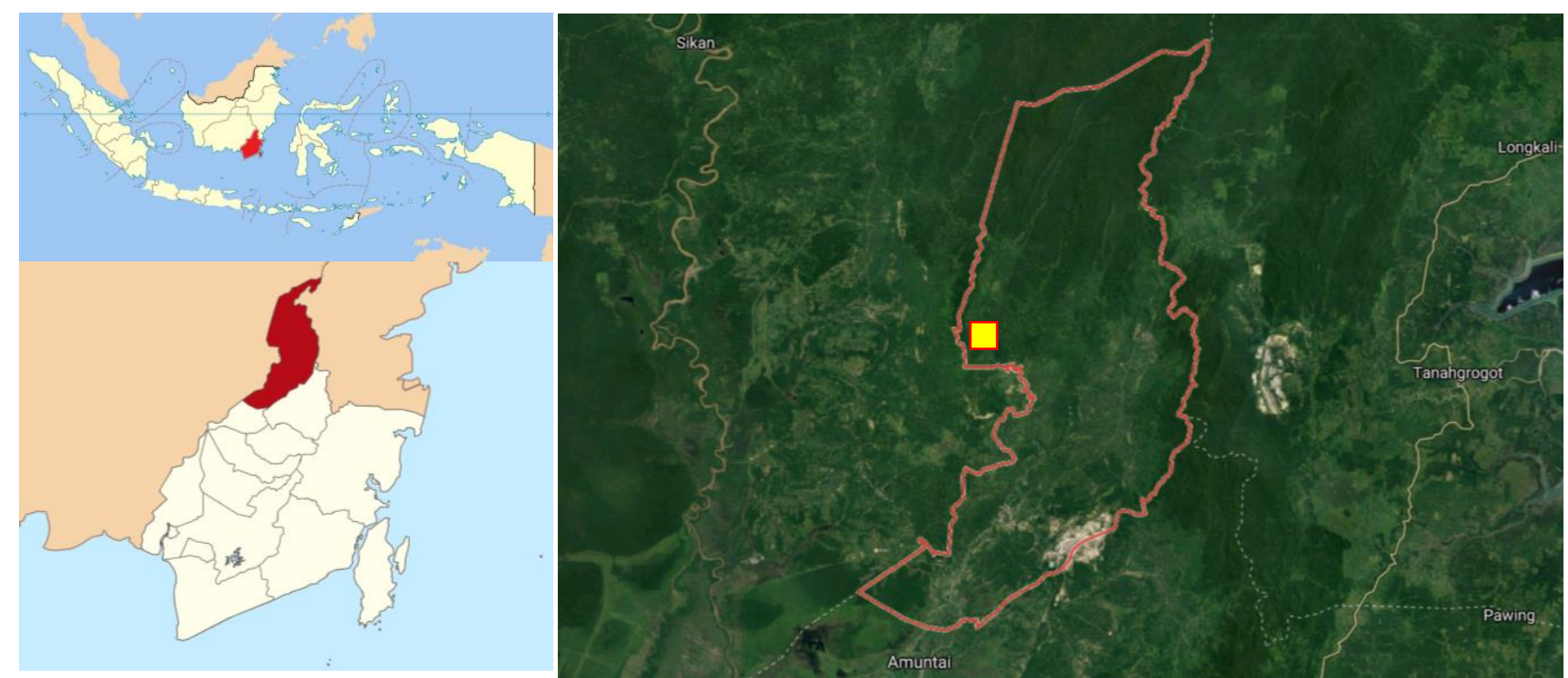

Figure 1. Map of the study site in Dambung Raya Village ( $\square$ ), Tabalong District, South Kalimantan Province, Indonesia 
Identification to species level referred to living collections in the Bogor Botanic Gardens as well as literature review (Comber 1990, 2001; Vermeulen 1991; Seidenfaden and Wood 1992; Chan et al. 1994; Wood and Cribb 1994; Wood 1997, 2001, 2003, 2013; Gravendeel 2000). Valid name was updated based on the database of The Plant List (2013).

\section{RESULTS AND DISCUSSION}

The forest area of the logging concession an altitude between 200 and 600 meters above sea level (m asl). The topography in the study site was a hilly mountain with steep slopes from $0-40 \%$. The soil consists of sandstone, limestone, rock and limestone, clay yellowish-white, red yellow Podsolic, red yellow Podsolic Latosol complex, and Litosol. The vegetation was dominated by species of Dipterocarpaceae family (Imanuddin and Wahjono 2007). Some dominant species were Tengkawang (Shorea stenoptera Burck), Jelutung (Dyera costulata (Miq.) Hook.f.), Artocarpus spp., Bangkirai (Shorea laevis Ridl.), Kapur (Dryobalanops spp.), Dungun (Syzygium sp.), Meranti (Shorea spp.), Nyatoh (Palaquium sp.), Kuranji (Dialium sp.), Madang (Litsea sp.), Binuang (Octomeles sumatrana Miq.) and Sindur (Sindora sp.) (Panjaitan et al. 2013). The study was carried out at an altitude between 200 and 326 (m asl). It had soil $\mathrm{pH}$ of 6.2-6.7 and air humidity (RH) of $54-72 \%$. The habitat can be described as secondary forest. The study recorded 65 orchid species belonging to 27 genera in which 64 were epiphytic orchids and one species was terrestrial orchid (Table 1). Recently, some genera have changed to new names. Genera Diplocaulobium and Flickingeria are reincluding in genus Dendrobium; some species of Eria are split into
Campanulorchis, Mycaranthes, and Pinalia. Details of the species found along with their habitus are presented in Table 1. The highest number of species found in this area was Dendrobium then followed by Bulbophyllum and Coelogyne. This data is shown in Figure 2.

Some interesting orchids with beautiful flowers recorded in the study location were Aerides odorata Lour, Acriopsis spp. (A. liliifolia (J.Koenig) Seidenf. and A.ridleyi Hook.f.), Coelogyne spp. (C. motleyi Rolfe ex J.J.Wood, D.A.Clayton \& C.L.Chan, C. foerstermannii Rchb.f., C. rochussenii de Vriese, C. aff. pandurata Lindl.), Grammatophyllum speciosum Blume, Liparis spp. (Liparis latifolia Lindl. and Liparis parviflora (Blume) Lindl., Pteroceras teres (Blume) Holttum, Thecostele alata (Roxb.) E.C.Parish \& Rchb.f., and Thrixspermum arachnites (Blume) Rchb.f. (Figure 2). Two species endemic to Borneo found in this area were Coelogyne motleyi Rolfe ex J.J.Wood, D.A.Clayton \& C.L.Chan. and Cleisostoma brachystachys (Ridl.) Garay.

\section{Notes on the species found in the study location \\ Adenoncos parviflora Ridl.}

There are six species of Adenoncos recorded in Borneo, which are Adenoncos sumatrana J.J.Sm., A. major Ridl., A. parviflora Ridl., A. buruensis J.J.Sm., A. triloba Carr, A. virens Blume. The species found in this area were identified as A. parviflora Ridl. This species is an epiphyte orchid and was found attached to a rotten tree trunk. The stem is erect to pendant, with a basally branching stem enveloped completely by leaf. It has thick fleshy leaves, linear, acute, and basally clasping leaves. It has 1-4 flowers in a cluster at each node all in a close row. It grows in the lowlands of mixed dipterocarp at an altitude of 270-340 m.

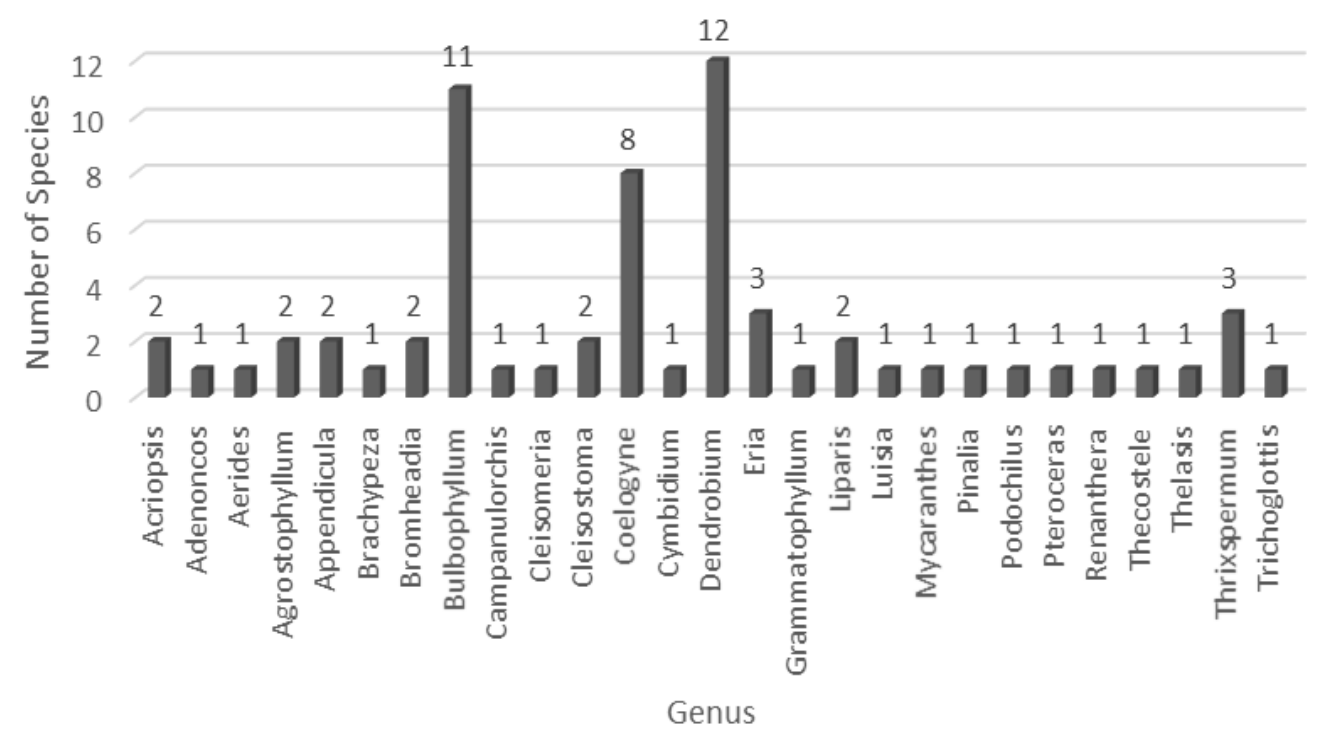

Figure 2. Number of orchid species for each genus found in logging concession in Dambung Raya Village, South Kalimantan Province, Indonesia 
Table 1. Orchid diversity in a logging concession in Dambung Raya village, Tabalong District, South Kalimantan, Indonesia

\begin{tabular}{|c|c|}
\hline Name of orchid & Habitus \\
\hline Acriopsis aff. ridleyi Hook.f. & Epiphyte \\
\hline Acriopsis liliifolia (J.Koenig) Seidenf. & Epiphyte \\
\hline Adenoncos parviflora Ridl. & Epiphyte \\
\hline Aerides odorata Lour. & Epiphyte \\
\hline Agrostophyllum elongatum (Ridl.) Schuit. & Epiphyte \\
\hline Agrostophyllum stipulatum (Griff.) Schltr. & Epiphyte \\
\hline Appendicula cornuta Blume & Epiphyte \\
\hline Appendicula undulata Blume & Epiphyte \\
\hline Brachypeza indusiata (Rchb.f.) Garay & Epiphyte \\
\hline Bromheadia aporoides Rchb.f. & Epiphyte \\
\hline Bromheadia finlaysoniana (Lindl.) Miq. & Terrestrial \\
\hline Bulbophyllum aff. acuminatum (Ridl.) Ridl. & Epiphyte \\
\hline $\begin{array}{l}\text { Bulbophyllum aff. cornutum (Blume) Rchb.f.-DM } \\
2728\end{array}$ & Epiphyte \\
\hline Bulbophyllum aff. dearei (Rchb.f.) Rchb.f. & Epiphyte \\
\hline Bulbophyllum aff. flabellum-veneris (J.Koenig) Aver. & Epiphyte \\
\hline Bulbophyllum binnendijkii J.J.Sm. & Epiphyte \\
\hline Bulbophyllum odoratum (Blume) Lindl. & Epiphyte \\
\hline Bulbophyllum penduliscapum J.J.Sm. & Epiphyte \\
\hline Bulbophyllum purpurascens Teijsm. \& Binn. & Epiphyte \\
\hline Bulbophyllum sp.-DM 2712 & Epiphyte \\
\hline Bulbophyllum sp.-DM 2734 & Epiphyte \\
\hline Bulbophyllum vaginatum (Lindl.) Rchb.f. & Epiphyte \\
\hline $\begin{array}{l}\text { Campanulorchis leiophylla (Lindl.) Y.P.Ng \& } \\
\text { P.J.Cribb) }\end{array}$ & Epiphyte \\
\hline Cleisomeria lanatum (Lindl.) Lindl. ex G.Don & Epiphyte \\
\hline Cleisostoma brachystachys (Ridl.) Garay & Epiphyte \\
\hline Cleisostoma suaveolens Blume & Epiphyte \\
\hline Coelogyne aff. pandurata Lindl. & Epiphyte \\
\hline Coelogyne aff. septemcostata J.J.Sm. & Epiphyte \\
\hline Coelogyne aff. swaniana Rolfe & Epiphyte \\
\hline Coelogyne asperata Lindl. & Epiphyte \\
\hline Coelogyne foerstermannii Rchb.f. & Epiphyte \\
\hline Coelogyne motleyi Rolfe ex J.J.Wood, & Epiphyte \\
\hline D.A.Clayton \& C.L.Chan & \\
\hline Coelogyne pulverula Teijsm. \& Binn. & Epiphyte \\
\hline Coelogyne rochussenii de Vriese & Epiphyte \\
\hline Cymbidium aff. finlaysonianum Lindl. & Epiphyte \\
\hline Dendrobium acerosum Lindl. & Epiphyte \\
\hline Dendrobium bancanum J.J.Sm & Epiphyte \\
\hline Dendrobium brevicolle J.J.Sm. & Epiphyte \\
\hline Dendrobium capituliflorum Rolfe & Epiphyte \\
\hline Dendrobium grande Hook.f. & Epiphyte \\
\hline Dendrobium lampongense J.J.Sm. . & Epiphyte \\
\hline Dendrobium lobulatum Rolfe ex J.J.Sm. & Epiphyte \\
\hline Dendrobium plicatile Lindl. & Epiphyte \\
\hline Dendrobium sp. DM 2717 & Epiphyte \\
\hline Dendrobium sp. DM 2738 & Epiphyte \\
\hline Dendrobium sp. DM 2739 & Epiphyte \\
\hline Dendrobium truncatum Lindl. & Epiphyte \\
\hline Eria nutans Lindl. & Epiphyte \\
\hline Eria sp. DM 2748 & Epiphyte \\
\hline Grammatophyllum speciosum Blume & Epiphyte \\
\hline Liparis latifolia Lindl. & Epiphyte \\
\hline Liparis parviflora (Blume) Lindl. & Epiphyte \\
\hline Luisia sp. DM 2692 & Epiphyte \\
\hline Mycaranthes pannea (Lindl.) S.C.Chen \& J.J.Wood) & Epiphyte \\
\hline Pinalia floribunda (Lindl.) Kuntze & Epiphyte \\
\hline Pinalia recurvata (Hook.f.) Kuntze & Epiphyte \\
\hline Podochilus densiflorus Blume & Epiphyte \\
\hline Pteroceras teres (Blume) Holttum & Epiphyte \\
\hline Renanthera sp. DM 2715 & Epiphyte \\
\hline
\end{tabular}

\begin{tabular}{ll}
\hline Thecostele alata (Roxb.) E.C.Parish \& Rchb.f. & Epiphyte \\
Thelasis carinata Blume & Epiphyte \\
Thrixspermum raciborskii J.J.Sm. subsp. & Epiphyte \\
brevipollinium P. O'Byrne \& A. Ent & \\
$\begin{array}{l}\text { Thrixspermum scopa (Rchb.f. ex Hook.f.) Holttum } \\
\text { Thrixspermum sp.-DM } 2726\end{array}$ & Epiphyte \\
Trichoglottis geminata (Teijsm. \& Binn.) J.J.Sm. & Epiphyte \\
& Epiphyte
\end{tabular}

\section{Acriopsis spp.}

Genus Acriopsis is an epiphyte orchid which consists of only 6 species in the world, spread from Sikkim, Assam (India), the Solomon Islands, Southeast Asia, Papua New Guinea to Australia (Comber 1990). It grows well in the lowlands to the mountainous areas $(0-1.000 \mathrm{~m})$. These two species were found in this area, namely Acriopsis aff. ridleyi Hook.f. and Acriopsis liliifolia (Koen.) Ormerod. They were found in lowland secondary forest at an altitude of 231-326 m. They are both very easy to distinguish, $A$. ridleyi has unbranched inflorescence (O'Byrne 2011) and A. liliifolia has long branching inflorescence (Comber 1990).

\section{Aerides odorata Lour.}

This species is common found in lowland area below $500 \mathrm{~m}$ asl (Comber 1990). In this area, it was found at 326 $\mathrm{m}$ asl. It is widely distributed from India to over most of South-East Asia. This species can be distinguished from others by the fragrant flowers. It is a monopodial epiphyte orchid with strap-shaped leaves places in two rows. Leaves tough and thick, with bilobed apex. Inflorescence axillar, the peduncle supports 20-30 flowers. Flowers are white with or without pink-purple spotting and blotching, fragrant. Lips trilobed and spurred, spur curved forward like a nail with a pointy tip.

\section{Agrostophyllum spp.}

There were two species of Agrostophyllum found in this study namely Agrostophyllum stipulatum (Griff.) Schltr. and Agrostophyllum elongatum (Ridl.) Schuit. Only Agrostophyllum stipulatum (Griff.) Schltr., which was formerly known as Agrostophyllum bicuspidatum J.J.Sm., can be easily distinguished from other species. It has a single or two flowers. Both were found at $200 \mathrm{~m}$ asl.

The Agrostophyllum genus is not very exciting orchids, because the flowers are small and usually whitish or yellowish, globular heads of many flowers, and dry by the time the flowers open. The center of distribution of this genus is mostly in tropical countries, and in Borneo there are 15 species (Comber 1990). A. stipulatum commonly grows at an altitude of 200-1,400 m asl. and often forming large clumps. This orchid is widespread in Southeast Asia to the Salomon Islands (Comber 1990). While $A$. elongatum which is formerly known as Appendicula elongata Ridl. commonly grows in lowland forest in shaded positions at an altitude of 90-1,000 m asl. and can be found on tree branches in secondary rainforest with humus and moss. This species is widespread in Malesia (Peninsular Malaysia, Sumatra, Java, Borneo, Sulawesi, Moluccas, New Guinea, The Philippines, Solomon Islands, Vanuatu, Carolines (O'Byrne 1994). 

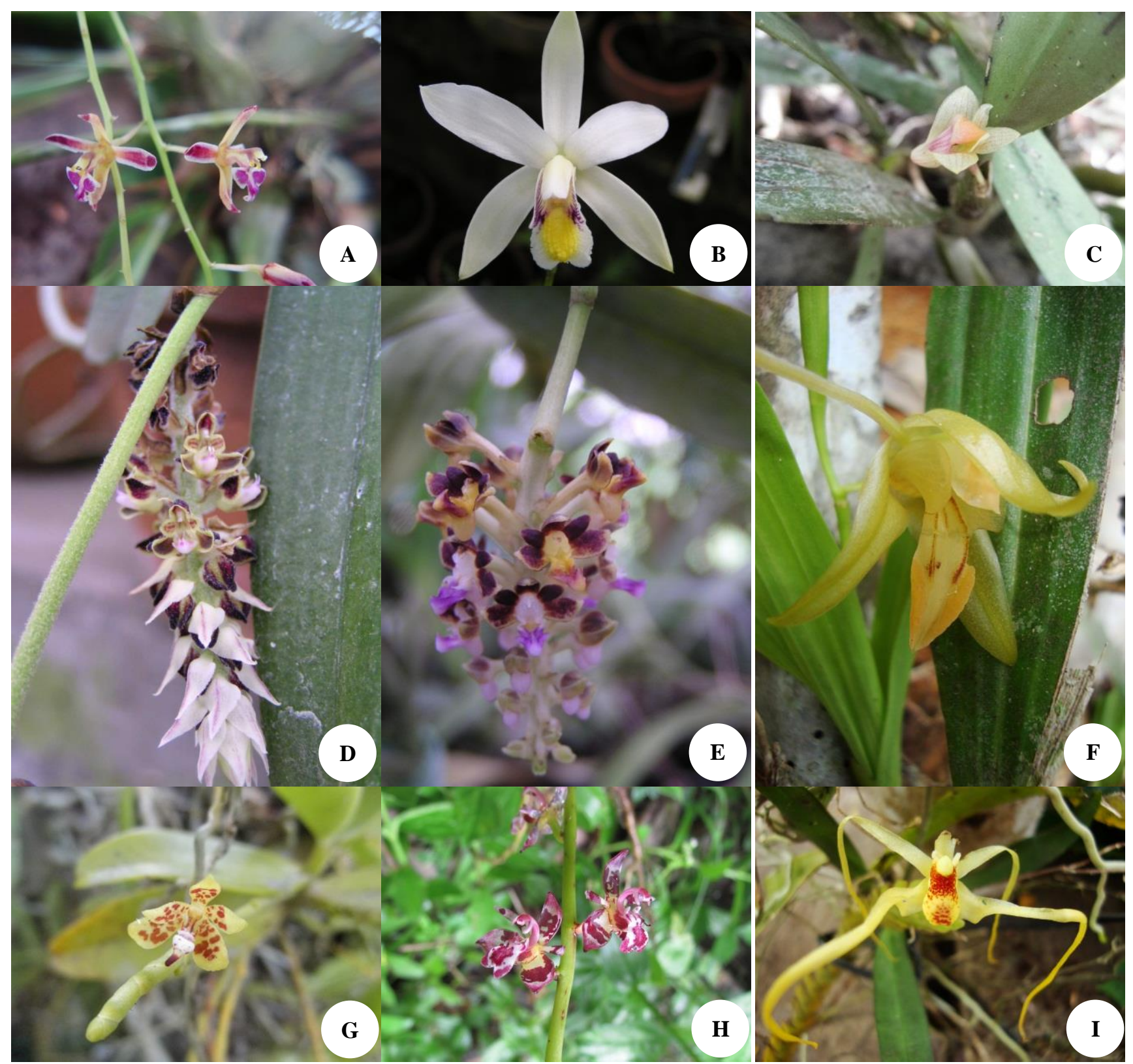

Figure 3. Orchids in Dambung Raya village, Bintang Ara Sub-district, Tabalong District, South Kalimantan, Indonesia. A. Acriopsis liliifolia (J.Koenig) Seidenf.; B. Bromheadia finlaysoniana (Lindl.) Miq.; C. Dendrobium bancanum J.J.Sm; D. Cleisomeria lanatum (Lindl.) Lindl. ex G.Don; E. Cleisostoma aff. brachystachys (Ridl.) Garay; F. Coelogyne motleyi Rolfe ex J.J.Wood, D.A.Clayton \& C.L.Chan; G. Pteroceras teres (Blume) Holttum; H. Thecostele alata (Roxb.) E.C.Parish \& Rchb.f.; I. Thrixspermum raciborskii J.J.Sm. subsp. brevipollinium P. O'Byrne \& A. Ent

\section{Appendicula spp.}

There were two species of Appendicula found in this study: Appendicula cornuta Blume and Appendicula undulata Blume. These orchids are sympodial plants without pseudobulb. Epiphytes on the stem host plant, leaves placed in two rows. Inflorescence of $A$. cornuta is terminal, and A. undulata has both terminal and lateral inflorescences.

Appendicula cornuta is widely distributed from China, Hong Kong, Assam, Himalayan, Myanmar, Thailand, Cambodia, Vietnam, Malaysia, Philippines, Sumatra, Borneo, Java, Celebes (Sulawesi). Growing in damp forest at an altitude of 500-1,500 m. While Appendicula undulata is found in Peninsular Malaysia, Sumatra, Java, and Borneo, at an altitude of 400-1,000 m. (Comber 1990). In this area, A. cornuta was found at range of 200-326 m altitude, while A. undulata was found on tree branches in secondary rainforest at $251 \mathrm{~m}$ above sea level.

\section{Brachypeza indusiata (Rchb.f.) Garay}

Brachypeza indusiata (Rchb.f.) Garay is a monopodial epiphyte orchid with short stem which is covered by alternate leaves. The leaves are oval-shaped and widened at the ends, thick and fleshy, $25 \mathrm{~cm}$ long and $5.5 \mathrm{~cm}$ wide, 
green. Inflorescence arising from a lower axil, pendulous or bent downwards, densely many-flowered, $24-30 \mathrm{~cm}$ long. inflorescences are $8 \mathrm{~cm}$ long with thick rachis and carry very dense flowers with a short life. Flowers are pale yellow with a few transverse brown streaks. (Seidenfaden and Wood 1992; Wood 2003).

It grows in lowland forest to hill forest at elevations of 5 to 300 meters asl. in shaded positions. It is widely distributed in Malesia (Peninsular Malaysia, Sumatra, Borneo, Sulawesi, Moluccas, New Guinea) (Seidenfaden and Wood 1992; Wood 2003). In this study area, it was found attached to the main stem in secondary forest at an altitude of $200 \mathrm{~m}$ asl.

\section{Bromheadia spp.}

There were two species of Bromheadia in the study location, namely Bromheadia finlaysoniana (Lindl.) Miq. and Bromheadia aporoides Rchb.f. The terrestrial orchid of $B$. finlaysoniana is growing in a clump with close-set stem, 1-1.5 m high with stiff leaves, rarely branching. The flowers white and yellow interiors with mauve to pinkpurple exteriors, 5-6 cm in diameter. This species has a wide distribution that includes Thailand, Laos, Cambodia, Vietnam, Malaysia, Sumatra, Borneo, Moluccas, New Guinea, and the Philippines in open scrub and light montane forests at elevations of $50-1,500 \mathrm{~m}$ asl. (Seidenfaden and Wood 1992; Kruizinga 1997; Wood and Cribb 1994). In this study area, it was found in an open area at an altitude of $251 \mathrm{~m}$ with $70 \%$ air humidity and soil acidity was around 6,7.

Bromheadia aporoides is an epiphyte with leafy canelike, leafy stems. Leaves are distichous, acute, clasping basal leaf sheaths. Inflorescence supports 1 to 3 flowers in opposite ranks, $2 \mathrm{~cm}$ cross, only a few flowers open at a time. Found in Myanmar, Thailand, Malaysia, Laos, and Borneo at elevations around 300-1,600 m asl. in hill and montane forests as a miniature sized (Seidenfaden and Wood 1992; Kruizinga 1997). In this study area, it was found on tree branches in secondary forest at an altitude of $286 \mathrm{~m}$ asl.

\section{Bulbophyllum spp.}

There were eleven species of Bulbophyllum found in this area. These orchids are mostly epiphyte with creeping rhizomes, sympodial with pseudobulbs placed at varying intervals on the rhizome. But not much in flowering time, so they have not been identified precisely to species. There are several species of flowering after being planted in the botanical garden so some of them can be identified as species such as Bulbophyllum aff. acuminatum (Ridl.) Ridl., Bulbophyllum binnendijkii J.J. Sm., Bulbophyllum aff. flabellum-veneris (J.Koenig) Aver., Bulbophyllum aff. dearei (Rchb.f.) Rchb.f., Bulbophyllum aff. cornutum (Blume) Rchb.f., Bulbophyllum penduliscapum J.J.Sm., Bulbophyllum purpurascens Teijsm. \& Binn., Bulbophyllum odoratum (Blume) Lindl. and Bulbophyllum vaginatum (Lindl.) Rchb.f. According to Comber (1990), Bulbophyllum binnendijkii J.J. Sm. is a Javanese endemic orchid. However, Puspitaningtyas (2009) has found in Central Kalimantan as a new record after the flower blooming, the plant can be identified as B. binnendijkii. However, other Bulbophyllum cannot be identified without flowering specimens, because there are many species with the same morphology of leaf and bulb. Identifying species names can not only be seen from the morphological structure of the plant, but also from the structure of the flowers.

\section{Campanulorchis leiophylla (Lindl.) Y.P.Ng \& P.J.Cribb}

It was previously placed in the genus Eria namely $E$. leiophylla Lindl. These epiphytic orchids are growing sympodial. Rhizome rather stout, the erect shoots about 2-6 $\mathrm{cm}$ apart. Sheats of growing shoots are covered with redbrown woolly hairs. Pseudobulbs are ovoid, narrowed to the end, 4.5-9 cm long, and $1-2 \mathrm{~cm}$ thick at the base, supports 2 leaves at the top. Leaves are elliptic-oblong, 15$18 \mathrm{~cm}$ long, and 1.7-2.5 cm wide. This genus is very easy to identify because after the flower stalk falls, it will leave a hole mark at the bulb stem. . It is distributed in Peninsular Malaysia, Borneo, Sumatra, Sulawesi, and Moluccas (Maluku). It is common found on lowland limestone hills, peat swamp forests, and lower montane forests from sea level to 2000 meters altitude. Exposed situations are preferred, such as high tree branches or on the crowns of trees (O'Byrne 2001). In this study area, it was found on tree branches in secondary forest at an altitude of $251 \mathrm{~m}$.

\section{Cleisomeria lanatum (Lindl.) Lindl. ex G. Don}

A genus of two species, recognized by the dense manyflowered often branching inflorescence with floral bracts that much longer than the leaves. This epiphytic orchid has a short monopodial stem, erect, stout, carrying linearoblong and distichous leaves, overlapping at the base. Inflorescences $10-17.5 \mathrm{~cm}$ in length, are filled with small and dense flower. Lateral sepals spreading, petals pale yellow-greenish color base, the outer sepals, and petal brownish-red, slightly feathery, the inside petal vaguely streaked red-brown, flower diameter $5 \mathrm{~mm}$. it is widely distributed from Burma, Thailand, Malaysia, Cambodia, Laos, Vietnam (Indochina) (Seidenfaden and Wood 1992). In Indonesia, it is recorded in Kalimantan, but it has found a new record in Sumatra in Tanggamus District, Lampung. Specimen was collected in 2012.

\section{Cleisostoma spp.}

There were two species of genera Cleisostoma found growing in this area, namely Cleisostoma aff. brachystachys (Ridl.) Garay and Cleisostoma suaveolens Blume. They are both occur in Borneo. C. brachystachys is endemic to Borneo and C. suaveolens distributes in Java, Sumatra, Bali, and Borneo (Comber 1990). Generally it grows in the lowlands, it was found at an altitude of $251 \mathrm{~m}$ asl. Cleisostoma brachystachys is very similar to Cleisostoma suaveolens. The differences between them are in the apex of the lip crease and in the color of the tepals. In addition, $C$. brachystachys has much rounder, fuller spurs, and a short peduncle that hold the racemose inflorescence close to the leaves. $C$. suaveolens has pendulous inflorescences, often unbranched but sometimes with short branches, that hold flowers away from the 
axillary of the leaves. The apex of the lip is very erose and curving inwards. They were found on tree branches in secondary forest at an altitude of 251-326 m.

\section{Coelogyne spp.}

Coelogyne is a genus with approximately 200 species occurring from Central Asia southward through Malaya and Indonesia into the Indopacific region. The characteristics of this genus are sympodial, pseudobulbs of one internode, one or two leaves, terminal inflorescences, a wing column, and massive caudicles (Dressler 1981; Gravendeel 2000).

There were eight species of Coelogyne found in this area, namely Coelogyne asperata Lindl., Coelogyne foerstermannii Rchb.f., Coelogyne motleyi Rolfe ex J.J.Wood, D.A.Clayton \& C.L.Chan, Coelogyne aff. pandurata Lindl., Coelogyne pulverula Teijsm. \& Binn., Coelogyne rochussenii de Vriese, Coelogyne aff. septemcostata J.J.Sm., Coelogyne aff. swaniana Rolfe. Some species are vegetatively easily recognized and distinguished for each other although not flowering, which is C. asperata, C. foerstermannii, C. pulverula, and $C$. rochussenii. There is one species of Coelogyne which included in section Verrucosae Pfitzer \& Kraenzlin, has flattened pseudobulb but not flowering. It can be possibly identified as $C$. pandurata Lindl., $C$. verrucosa S.E.C. Sierra, C. peltastes Rchb.f., C. marthae S.E.C. Sierra, or $C$. zurowetsii Carr., those are species occur in Borneo (Gravendeel 2000).

\section{Cymbidium sp.}

Only one species of this genus was found and could not be identified to species. The plant still young and not in flowering time when collected. Based on the vegetative plant, it is affinity with Cymbidium finlaysonianum Lindl or C. atropurpureum (Lindl.) Rolfe, both are in Borneo. They have thick, hard, long leaves $(70-90 \mathrm{~cm})$ and widest leaves $(4-4.5 \mathrm{~cm})$ among the pendulous inflorescence in this genus. Flowers are needed for precise identification. $C$. finlaysonianum has yellow tepals with or without red streaks running along the middle, with recurved lip is white with red markings. While C.atropurpureum has dark maroon tepals, with recurved lip is white with burgundypurple spots.

\section{Dendrobium spp.}

Dendrobium is such a large and variable genus, and has been divided into sections (Schlechter 1911; Comber 1990). Six genera as constituting the subtribe Dendrobiinae (Cadetia Gaudich., Dendrobium, Diplocaulobium (Rchb.f.) Kraenzl., Epigeneium Gagnep., Flickingeria A.D.Hawkes (Ephemerantha P.F.Hunt \& Summerh.) and Pseuderia Schltr.) reincluded in Dendrobium, and now it is still discussed among plant taxonomists (Schuiteman 2011). Less than 6 species of Dendrobium, 1 species of Diplocaulobium, and 5 species of Flickingeria are found growing in this area. Dendrobium spp. (DM 2717, DM 2738, DM 2739), Dendrobium plicatile Lindl. and Dendrobium bancanum J.J.Sm. are previously belong to Flickingeria (the previous genus), they differ vegetatively based on the shape and size of the bulb and the texture of the leaves. Dendrobium brevicolle J.J.Sm. was previously named Diplocaulobium brevicolle (J.J.Sm.) Kraenzl. However, now those genera are reincluded in genus Dendrobium, returned to its former name and they only separated into section. After those genera reincluding in genus Dendrobium, so there were 12 species of Dendrobium were recorded in this study area.

\section{Eria spp.}

Approximately 6 species of Eria are found growing in this region. But some of the genus Eria is now become a synonym and revise to the new genus. For example Eria pannea Lindl. is a synonym of Mycaranthes pannea (Lindl.) S.C.Chen \& J.J.Wood as the new name; Eria leiophylla Lindl. is a synonym of Campanulorchis leiophylla (Lindl.) Y.P.Ng \& P.J.Cribb; Eria floribunda Lindl. is a synonym of Pinalia floribunda (Lindl.) Kuntze. However Eria nutans Lindl. is an accepted name (The Plant List. 2013), so not all Eria changes to a new genus. It was found in secondary forest at $251 \mathrm{~m}$ asl. While the other species of Eria (DM 2748) could not be identified precisely without flower specimen. It is still under observation. So there are two species of Eria found in this area.

\section{Grammatophyllum speciosum Blume}

Grammatophyllum consists of 3 species with two types of plant that are long pseudobulb stem-like with many strap leaves and conical pseudobulb with several lanceolate leaves. Grammatophyllum speciosum Blume has long pseudobulb stem-like with many strap leaves, can reach 3-7 $\mathrm{m}$ long. It is a giant orchid in the world. The inflorescences are about 1-2 m long and support 50-100 flowers. There are a few sterile or distorted flowers near the base. Flowers are yellow or greenish-yellow with reddish-brown spots or blotches,. It is widespread in South-East Asia to the Solomon Islands (Comber 1990).

\section{Liparis spp.}

There were two species of Liparis found in the study area, namely Liparis latifolia Lindl. and Liparis parviflora (Blume) Lindl. Those Liparis are small epiphytes with pseudobulb, inflorescence is terminal, and many-flowered. L. latifolia supports upright inflorescence and L. parviflora supports pendulous inflorescence. L. latifolia has small flower about $2 \mathrm{~cm}$ broad, brick red, bright red lip and curved to $180^{\circ}$. Generally it grows in the lowlands $250 \mathrm{~m}$ to a height of $1,700 \mathrm{~m}$ asl. It is widely spread in Thailand, Peninsular Malaysia, Java, Sumatra, Borneo, and New Guinea (Comber 1990). It was found in secondary forest at altitude of $326 \mathrm{~m}$

Liparis parviflora is known as the small Liparis, because the size of the flower is relatively small with a diameter of $0.6 \mathrm{~cm}$ but it has the longest inflorescences (70 $\mathrm{cm})$ compared to other species in the genus Liparis. The flowers are greenish yellow-reddish, with bright red lips, the apical lip is deeply bilobed and margins hairy. It is common found at elevations around sea level to 2,000 m asl. in shady lowland and montane forests. It is widespread to Thailand, Peninsular Malaysia, Borneo, Java, Sumatra, 
Sulawesi, Bali, Lesser Sunda Islands, New Guinea, and the Philippines (Comber 1990).

\section{Luisia sp.}

Nine species of the genus Luisia are recognized in Indonesia, the two of which native to Borneo (Sulistiarini 1988) that are Luisia antennifera Blume and L. zollingeri Rchb. f. The other one recorded occur in Borneo as well is L. curtisii Seidenf. (Chan et al. 1994). So there are three species of genus Luisia that occur in Borneo. The morphological characters of genus Luisia are the same, which are epiphytic or lithophytic, monopodial with cylinder, or terete leaves. Identifying the name of the species can not only be seen from the shape of the plant morphology. To identify species must look at the morphological structure of the flowers. So if there is no flower, the name of the species cannot be determined precisely. Character of the inflorescence is short with flowers open at a time. Fleshy flowers are placed close together on a thick rachis. Sepals and petals are mostly colored greenish or yellowish and lip is not moveable. In this area, the species of Luisia have not been identified because there was not flowering.

\section{Mycaranthes pannea (Lindl.) S.C.Chen \& J.J.Wood}

It was previously considered as a synonym of Eria pannea Lindl., but eventually it has become an accepted name. This epiphytic plant has thick and creeping rhizomes. Stems are very short, carrying 2-3 leaves. Leaves are fleshy, terete or cylindrical, pointed at the apex, 7 to 15 $\mathrm{cm}$ long. Inflorescence is terminal and bearing 1 to 3 fragrant flowers with wolly peduncle. Flowers about 1.6-2 $\mathrm{cm}$ across, sepals, and petals are bright yellow to greenish while opening and turns to orange in a day or two days. The backs of the flowers are pubescent (covered with white hairs). It is widely distributed from the eastern Himalayas and southern China southwards to Malaya, Sumatra, and Borneo. It is usually found in lowland forest (Seidenfaden and Wood 1992). In this area, it was found in secondary forest at $286 \mathrm{~m}$ asl.

\section{Pinalia spp.}

There were two species of genera Pinalia found growing in this area, namely Pinalia floribunda (Lindl.) Kuntze and Pinalia aff. recurvata (Hook.f.) Kuntze. Genus Pinalia is formerly known as Genus Eria.

Pinalia floribunda (Lindl.) Kuntze is an epiphytic plant that has erect sympodial pseudobulbs. The nodes on the upper half of matured pseudobulb produce 3-5 inflorescences at one time, usually is about $7-15 \mathrm{~cm}$ long, pendent, or spreading horizontally, with many resupinate flowers. The small white flowers are $5-8 \mathrm{~mm}$ across and maybe faintly tinged with pink. Found in Burma, Cambodia, Myanmar, Thailand, Vietnam, Peninsular Malaysia, Sumatra, Java, Borneo, and the Philippines in primary montane forests, at elevations of 500 to 2,400 meters (Seidenfaden and Wood 1992; https://www.orchidcambodia.com/eria-floribunda.html.). In this area, it was found in secondary forest at $231 \mathrm{~m}$ asl.
Pinalia recurvata (Hook.f.) Kuntze was formerly Eria recurvata Hook.f. It is an epiphyte orchid with a stout, fleshy stem. The leaves are elliptic, acute, and plicate. The inflorescence emerges from nodes below the leaves, to 15 $\mathrm{cm}$ long, with many flowers, yellow with purple veins. The bracts are broad, acute, and yellowish (Seidenfaden and Wood 1992). In this area, it was found in secondary forest at $200 \mathrm{~m}$ asl.

\section{Podochilus densiflorus Blume}

Based on plant habit, stems, and flowers, this collection is affinity into genus Podochilus section Diadena (http://www.orchidsnewguinea.com). This is a small sympodial epiphyte without pseudobulbs. The thin stems creep and branch, rooting on to the host. The leaves have two rows and thin, narrowly linear, acuminate. Flowers at the apex of the stems (terminal), successively singleflowered, transparent (clear) white with some pinky spot on the apex lip. This specimen of Podochilus densiflorus was found growing at the elevation of $326 \mathrm{~m}$ asl. P. densiflorus occurs in Borneo and New Guinea at elevations 50 to 400 $\mathrm{m}$ asl. (Wood and Cribb 1994; http://www.orchidspecies.com/poddensiflorus.htm).

\section{Pteroceras teres (Blume) Holttum}

It is an epiphytic orchid, with short and unbranched stems. Leaves are flat, oblong to lanceolate, oblique, 4 to 17 , the apex bilobed. Inflorescence arises from the stem segment across the leaf, gradually lengthening, pendulous, up to $10 \mathrm{~cm}$, supporting 3 to 6 small flowers, about $1 \mathrm{~cm}$ in diameter, sweetly scent. Sepals and petals white or yellow, spotted with red, lip is small and short, rounded, spur is white with red spot or not, the apical part dark red. It is widespread from India, Thailand, Myanmar, Laos, Cambodia, Vietnam, the Philippines, Borneo, Sumatra, Java, Lesser Sunda Islands, Sulawesi, and Moluccas. It is commonly growing in the lowlands until the mountains reach a height of 1,000 $\mathrm{m}$ asl. (Comber 1990). This specimen of Pteroceras teres was found growing at the elevation of $326 \mathrm{~m}$ asl.

\section{Renanthera sp.}

In this area, the Renanthera have not been identified as species because there was no flower. Flowers are the main character for distinguishing species in the genus Renanthera. In Borneo there are 4 species that has been described, that are Renanthera bella J.J. Wood, Renanthera elongata (Blume) Lindl., Renanthera isosepala Holttum, and Renanthera matutina (Blume) Lindl. $R$. bella is endemic orchid to Borneo (Chan et al. 1994).

\section{Thecostele alata (Roxb.) Par. \& Rchb.f.}

Thecostele alata is an epiphyte orchid with pseudobulbs growing in clumps and close together. Each pseudobulb is derived from a single node and bears one leaf. The pendulous inflorescences emerge from the base, are not branched, and are many-flowered. Flowers are opening widely, $1.5 \mathrm{~cm}$ broad, white with variously blotched and spotted with dark crimson. This species generally grows at an altitude of 600-1.000 $\mathrm{m}$ above sea level, spread across 
Southeast Asia, Sumatra, Java, Borneo, and the Philippines (Comber, 1990). This species was found growing at $326 \mathrm{~m}$ altitude, attached to a branch of rotted tree.

\section{Thelasis carinata Blume}

Only one species of Thelasis found in this region, it is Thelasis carinata Blume. This species has a short stem topped by a fan of 3-5 leaves, one leaf from the apex, and 3-4 leaves from the base. The inflorescences emerge from the lower leaf axils, with many tiny flowers (10-20 flowers) that hardly open. $T$. carinata grows in the lowlands from sea level to mountains with an altitude of $800 \mathrm{~m}$ asl. It is widespread from Myanmar, Thailand, Peninsular Malaysia, Java, Sumatra, Borneo, Bali, Sulawesi, and the Philippines (Comber, 1990; O’Byrne 2001). This species was found growing at the elevation of $251 \mathrm{~m}$ altitude.

\section{Thrixspermum spp.}

There were two species of Thrixspermum found in this area, which are Thrixspermum raciborskii J.J.Sm. subsp. brevipollinium P. O'Byrne \& A. Ent (O’Byrne 2016), and Thrixspermum aff. scopa (Rchb.f. ex Hook.f.) Holttum. These orchids are a monopodial orchid, widespread over the whole of Southeast Asia (Comber 1990; O'Byrne 2001).

No form of Thrixspermum raciborskii has previously been recorded from Borneo (Comber, 1990; ), and Peter O'Byrne has described Thrixspermum raciborskii J.J. Sm. subsp.brevipollinium P. O’Byrne \& A. Ent, from Borneo as subspecies nova. So this species is endemic to Borneo and scrambling through branches of riverside shrubs and trees in primary forest on coal and ultramafic substrates, 50-250 m (O'Byrne 2016). It differs from Thrixspermum raciborskii subsp. raciborskii in having broader pollinia, ratio length: width is 3.5: 1 or less. In all other respects, it lies well within the range of variation of plants of Thrixspermum raciborskii subsp. raciborskii from Peninsular Malaysia, Sumatra, and Java (O'Byrne 2016). This specimen of Thrixspermum raciborskii J.J. Sm. subsp.brevipollinium was found growing at the elevation of $326 \mathrm{~m}$ asl.

Thrixspermum scopa (Rchb.f. ex Hook.f.) Holttum is a hot growing epiphyte orchid with a climbing stem, carrying fleshy and oblong leaves with apical bilobed and rounded. Inflorescence is arising from the stem below the leaves with peduncle, successively single flowered on widening and bracteate rachis. Flowers are greenish-yellow, size 15 $\mathrm{cm}$ abroad with linear sepals and petals. It is found in Thailand, Malaysia, and Borneo at elevations around sea level to $300 \mathrm{~m}$ asl (Seidenfaden and Wood 1992). This specimen of Thrixspermum scopa was found growing at the elevation of $251 \mathrm{~m}$ asl.

\section{Trichoglottis geminata (Teijsm. \& Binn.) J.J.Sm.}

This monopodial-epiphytic orchid has cylindrical stems, up to $2 \mathrm{~m}$ long, branch freely. The Inflorescences emergence from the node stem at the opposite leaf, 1-2 flowers. Flowers are greenish-yellow with brownish-red stripes, about $2 \mathrm{~cm}$ in diameter and they are sweetly fragrant. The lip is white with purple stripes and hairy.
Trichoglottis geminata is previously suspected of endemic species from the Philippines, but in fact, this species also grows in the area of Borneo, Sulawesi, and Moluccas (O’Byrne 2001). Puspitaningtyas (2011) also found this species in Buton island and in Wawonii islandSoutheast Sulawesi (Suliastiarini et al. 2007; Sulistiarini 2008). This species generally occur in the lowlands forest to $1,100 \mathrm{~m}$ altitude with sufficient sunlight conditions (O'Byrne 2001). This species was found growing at the elevation of $326 \mathrm{~m}$ altitude.

In conclusion, the orchid inventory in a logging concession in the village of Dambung Raya, Ara Bintang Sub-district, Tabalong District, South Kalimantan recorded 64 species of epiphyte orchids and one species of terrestrial orchid which belong to 27 genera. Some interesting orchid species collected from this area were Aerides odorata Lour., Acriopsis spp. (A.liliifolia (J. Koenig) Seidenf. and A. aff. ridleyi Hook.f.), Coelogyne spp. (C. motleyi Rolfe ex J.J.Wood, D.A.Clayton \& C.L.Chan, C. foerstermannii Rchb.f., C. rochussenii de Vriese, C. aff. pandurata Lindl.), Grammatophyllum speciosum Blume, Liparis latifolia Lindl., Pteroceras teres (Blume) Holttum, Thecostele alata (Roxb.) E.C.Parish \& Rchb.f., Thrixspermum raciborskii J.J. Sm. subsp. brevipollinium P. O'Byrne \& A. Ent etc. Orchid endemic to Borneo found in this area included Coelogyne motleyi Rolfe ex J.J.Wood, D.A. Clayton \& C.L. Chan, Cleisostoma brachystachys (Ridl.) Garay and Thrixspermum raciborskii J.J. Sm. subsp.brevipollinium P. O'Byrne \& A. Ent. These endemic orchids need to be protected from extinction in the wild, so plant conservation is recommended both in-situ and ex-situ. Conservation by reintroduction programs should be carried out to restore the populations in their natural habitat. Besides these three orchids are endemic to Borneo, they are also new collections for Bogor Botanic Gardens. The existence of orchids has become rare and endangered due to overexploitation of commercially traded, as well as habitat destruction. Although CITES (the Convention on International Trade in Endangered Species of Wild Fauna and Flora) about orchid has been established to protect orchid, in fact orchid species have still been threatened in the wild.

\section{ACKNOWLEDGEMENTS}

This study was financially supported by the Center for Plant Conservation, Botanic Gardens, LIPI. The author would like to thank a logging concession, PT. Aya Yayang Indonesia (AYI Ltd. Co.), who gave permission for doing research in their area. We thank Agung Sriyono, the head of Banua Botanic Gardens, and the exploration team (Wihermanto, Sumarno, Usman, Caca Sulaeman, Syaifuddin, Edi Suryanto, Nur Muchammad Azizi Kurniawan and Mujiburrahman)

\section{REFERENCES}

Ashton PW. 1982. Dipterocarpaceae. In van Steenis CGGJ. (eds) Flora Malesiana, series I. Spermatophyta. 9: 257-552. 
Budiharta S, Widyatmoko D, Irawati, Wiriadinata $\mathrm{H}$, Rugayah, Partomihardjo T, Ismail, Uji T, Keim AP, Wilson KA. 2011. The processes that threaten Indonesian plants. Fauna Flora International Oryx 45 (2): 172-179.

Chan CL. Lamb A. Shim PS. Wood JJ. 1994. Orchids of Borneo. Vol.1 Introduction and Selection of Species. The Sabah Society Kota Kinabalu-Royal Botanic Gardens Kew, UK.

Comber JB. 1990. Orchids of Java. Bentham-Moxon Trust \& The Royal Botanic Gardens, Kew, UK.

Comber JB. 2001. Orchids of Sumatra. The Royal Botanic Gardens, Kew. UK.

Dressler RL. 1981. The orchids natural history and classification. Harvard University Press. Cambridge, Massachusetts and London, England.

Global Forest Watch. 2020. Primary Forest Loss in Kalimantan Selatan, Indonesia. $\quad 1 \quad$ September 2020 https://www.globalforestwatch.org/dashboards/country/IDN/?categor $\mathrm{y}=$ summary \&dashboardPrompts.

Gravendeel B. 2000. Reorganising the Orchid genus Coelogyne: a phylogenetic classification based on morphology and molecules. Nationaal Herbarium Nederland, Universiteit Leiden branch, Nederland.

Hidayat S, Puspitaningtyas DM, Hartini S, Munawaroh E, Astuti IP, Wawangningrum H. 2017. . Eksplorasi Flora: 25 Tahun Menjelajah Rimba Nusantara. (Flora Exploration: 25 Years Exploring the Jungle of the Indonesian Archipelago). LIPI Press, Jakarta. [Indonesian]

http://www.orchidsnewguinea.com/orchidinformation/species/speciescode/858. Acces on 17 February 2020.

http://www.orchidspecies.com/poddensiflorus.htm. Acces on 24 March 2020.

https://www.orchidcambodia.com/eria-floribunda.html__Acces on 15 May 2020.

Imanuddin R. Wahjono D. 2007. Dynamics of Vegetation Cover and Forest Volume Based on Landsat Image in South Kalimantan (Dinamika Perubahan Penutupan Vegetasi Dan Potensi Hutan Berdasarkan Citra Landsat Di Kalimantan Selatan). Jurnal Penelitian Hutan dan Konservasi Alam 4 (3): 211-221.

Kruizinga J. van Scheindelen HJ. de Vogel EF. 1997. Revision of the genus Bromheadia (Orchidaceae). Orchid Monographs 8: 79-118.

Lamb A. 1991. Orchids of Sabah and Sarawak. In: Kiew, R. (eds) The State of Nature Conservation in Malaya. Malayan Nature Soc. \& IDRC, Canada.

MacKinnon K. Hatta G. Halim H. Mangalik A. 1996. The Ecology of Kalimantan: Indonesian Borneo. Periplus Editions (HK) Ltd. Singapore.

O’Byrne P. 1994. Lowland orchids of Papua New Guinea. Singapore Botanic Gardens. Singapore

O'Byrne P. 2001. A to Z of South East Asian Orchid Species. Orchid Society of South East Asia, Singapore.

O’Byrne P. 2014. Coelogyne motleyi Rolfe ex J.J. Wood. http://orchid.unibas.ch/ phpMyHerbarium/181915/1/Coelogyne/motleyi//specimen.php.

O'Byrne P. 2016. Thrixspermum in Borneo; 24 New and Old Species. Malesian Orchid Journal.18: 5-74

O'Byrne P. 2011. A to Z of South East Asian Orchid Species Vol. 2. Orchid Society of South East Asia, Singapore.

Panjaitan S. Lazuardi D. Rahmanto B. 2013. Analysis of The Efffectvity of Gap Simulation Silvicultural System in The Enhancement of Production Forest Productivity and Sustainability (Kajian Efektivitas Sistem Silvikultur Tebang Rumpang Terhadap Peningkatan Produktifitas Dan Kelestarian Hutan Alam Produksi). Jurnal Penelitian Dipterokarpa 7 (2): 109-122. [Indonesian]
Park SY, Murthy HN, Paek KY. 2000. In vitro seed germination of Calanthe sieboldii, an endangered orchid species. J Plant Biol 43: 158-161.

Partomihardjo T. Rahajoe JS. 2004. Pengumpulan data ekologi tumbuhan dalam pedoman pengumpulan data keanekaragaman flora (The data collection of plant ecology in flora biodiversity data collection guidelines). In: Rugayah. Widjaja EA. Praptiwi (eds). Pusat Penelitian Biologi-LIPI, Bogor (Research Center for Biology LIPI, Bogor). [Indonesian]

Puspitaningtyas DM. 2009. Keanekaragaman anggrek di kawasan Sungai Busang, Kalimantan Tengah (Orchid diversity in Busang River, Central Kalimantan). Prosiding Konservasi Flora Indonesia dalam mengatasi dampak pemanasan global (Proceedings of Indonesian Flora Conservation in Overcoming the Impact of Global Warming), 14 July 2009. UPT Balai Konservasi Tumbuhan Kebun Raya 'Eka Karya' Bali - LIPI, Tabanan. [Indonesian]

Puspitaningtyas DM. 2011. Inventarisasi Keanekaragaman Anggrek di Suaka Margasatwa Lambusango dan Cagar Alam Kakenauwe-Pulau Buton (Inventory of Orchid Diversity at Lambusango Wildlife Reserve and Kakenauwe Nature Reserve-Buton Island). Prosiding Seminar Nasional Biologi (Proceedings of National Seminar on Biology), 24-25 September 2010. [Indonesian]

Schlechter R. 1911. The Orchidaceae of German New Guinea (English translation 1982). The Australian Orchid Foundation, Melbourne, Australia.

Seidenfaden G. Wood JJ. 1992. The Orchids of Peninsular Malaysia and Singapore (A Revision of R.E. Holttum: Orchids of Malaya.). Olsen \& Olsen, Fredensborg, Denmark.

Siregar C. 2008. Exploration and inventory of native orchid germplasm in West Borneo, Indonesia. HortScience 43 (2): 554-557.

Suliastarini D. 2008. Orchid Diversity of Wawonii Island. Berkala Penelitian Hayati 14: 21-27. [Indonesian]

Sulistiarini D, Sunarti S, Wiriadinata H. 2007. Orchid New Records from Wawonii Island. Biodiversitas 8 (2): 83-87. [Indonesian]

Sulistiarini D. 1988. The orchid genus Luisia in Indonesia. Reinwardtia 10(4): 383-398

The Plant List. 2013. Version 1.1. Published on the Internet; http://www.theplantlist.org/.

van Steenis CGGJ. 1971. Plant Conservation in Malaysia. Bull Jard Bot Nat Belg 41: 189-202.

Vermeulen JJ. 1991. Orchids of Borneo. Vol. 2 Bulbophyllum. BenthamMoxon Trust, Royal Botanic Gardens, Kew, England.

WCMC [World Conservation Monitoring Centre]. 1995. Indonesian threatened plants. Eksplorasi 2 (3): 9.

Whitmore TC. 1984. Tropical Rainforest of the Far East. 2nd ed. Oxford University Press, Oxford.

Wood JJ, Cribb PJ. 1994. A Checklist of the Orchids of Borneo. Royal Botanic Gardens, Kew, UK.

Wood JJ. 1997 Orchids of Borneo Vol. 3 The Sabah Society Kota Kinabalu in association with The Royal Botanic Gardens Kew Surrey, UK.

Wood JJ. 2001 Dendrochilum of Borneo Natural History Publications (Borneo), Kota Kinabalu in association with The Royal Botanic Gardens Kew Surrey, UK.

Wood JJ. 2003 Orchids of Borneo Vol. 4 The Sabah Society Kota Kinabalu in association with Royal Botanic Gardens Kew Surrey, UK

Wood JJ. 2013. A Guide Dendrobium of Borneo. Natural History Publications (Borneo), Kota Kinabalu.

WWF [World Wild Fund] 2020. Borneo Deforestation https://wwf.panda.org/our_work/our_focus/forests_practice/deforestat ion_fronts2/deforestation_in_borneo_and_sumatra.[20 August 2020] 